\title{
土壤流亡度と土壤の性質との關係に就て*
}

土土壤侵蝕化關与当研究 第1 1 報——

\section{市川 正已}

1. 序わが國化於ては, 自然資源の保全の問题が極的て最近飞, その

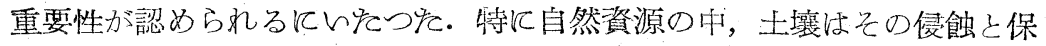
全策が直接地力の減粍, 維持灌關係して, 極的て重要少位置を占めている. 筆者は, 多摩丘陵(西生田一柿生) 飞於て，5個の谷学選んで，1948 年 4 月下旬から 8 月下旬の間で, 降雨封流亡する土褧の量を測定し, てれとそ の流域の土壤の性質との關係を精查した. 侗進んで土壤の侵蝕抵抗度及び 土壤侵蝕の機構を明か叱して, 開拓と土壤保全, 或は, 斜面形形成の問題 飞研究を進めをいと考えている。

2. 對象地域の選擇とその性質 筆者がこつで取报う地域は, 多摩丘陵 の中央部，小田急沿線の 5 個の小谷で西つて (1)，次の諸點汇留意して場所 を選擇しを。

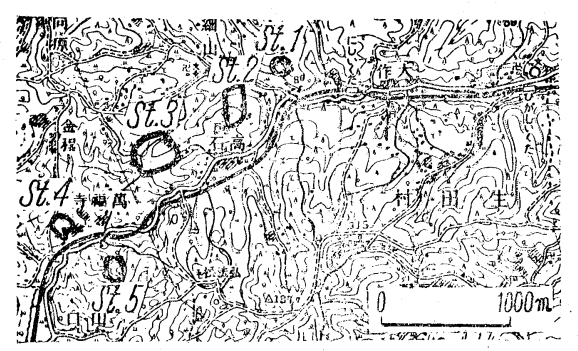

Fig. 1 Sites of Observation

1）流域の性質家成るぶく實 驗的裝置に近からしめるをめ, 小流域の谷定選んだ．2）降雨 時の夕流れる小流のある谷定選 んだ.3）植被の相違せる地域 莸選んだ. 邲ち, 林地 2 万所, 烟地 3 万所である.4) 土壤の 相違せる地域学選んだ。郎ち， 口一ム層の地域 3 万所, 新第三

系に由來しを土弶の坄域 2 万所老選擇した。

かくて選ばれを地域は Fig. 1 の如くですり，それ等の性質は Tab. 1 及び Fig. 6 で㐫る。

3. 調查の方法 降雨時各谷加ら流出する懸䍖液学，容量 $100 \mathrm{cc}$. 內徑 $0.3 \mathrm{~mm}$ の吸水口 2 万定有 る注射筒（西牧式注射筒）飞吸水しを. 採水 飞際しては，なる心゙流速に合致する如く筒內に吸水しを。流水の水深は

* 昭和 24 年 5 月 日本地理學會大會にて發表.

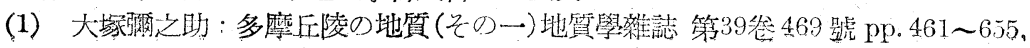


Tab. 1. Characteristics of Drainage Areas

\begin{tabular}{|c|c|c|c|c|c|c|c|}
\hline \multirow[b]{2}{*}{ St. } & \multirow[b]{2}{*}{$\begin{array}{l}\text { Area } \\
\text { (a) }\end{array}$} & \multirow{2}{*}{$\begin{array}{c}\text { Degree } \\
\text { of } \\
\text { Slope } \\
(\%)\end{array}$} & \multicolumn{4}{|c|}{ Vegetation $(\%)$} & \multirow[b]{2}{*}{ Soil } \\
\hline & & & $\begin{array}{l}\text { Wood } \\
\text { land }\end{array}$ & $\begin{array}{l}\text { Culti- } \\
\text { vated } \\
\text { field }\end{array}$ & $\begin{array}{l}\text { Grass } \\
\text { land }\end{array}$ & $\begin{array}{l}\text { Bare } \\
\text { land }\end{array}$ & \\
\hline 1 & $\begin{array}{r}68.8 \\
.\end{array}$ & $\begin{array}{l}<15 \\
<30 \\
<45 \\
>45\end{array}$ & $\begin{array}{r}5.0 \\
15.0 \\
40.0 \\
35.0\end{array}$ & $\begin{array}{l}- \\
- \\
-\end{array}$ & $\begin{array}{l}- \\
- \\
- \\
-\end{array}$ & $\begin{array}{l}5.0 \\
- \\
- \\
-\end{array}$ & Loam \\
\hline 2 & 212.5 & $\begin{array}{l}<15 \\
<30 \\
<45 \\
>45\end{array}$ & $\begin{array}{l}- \\
5.0 \\
- \\
20.0\end{array}$ & $\begin{array}{c}55.0 \\
15.0 \\
- \\
-\end{array}$ & $\begin{array}{l}5.0 \\
- \\
- \\
-\end{array}$ & $\begin{array}{l}- \\
- \\
-\end{array}$ & Lioam \\
\hline 3 & 381.5 & $\begin{array}{l}<15 \\
<30 \\
<45 \\
>45\end{array}$ & $\begin{array}{r}5.0 \\
5.0 \\
10.0 \\
-\end{array}$ & $\begin{array}{c}20.0 \\
20.0 \\
30.0 \\
-\end{array}$ & $\begin{array}{l}- \\
5.0 \\
- \\
-\end{array}$ & $\begin{array}{l}5.0 \\
- \\
- \\
-\end{array}$ & Loam \\
\hline 4 & 137.5 & $\begin{array}{l}<15 \\
<30 \\
<45 \\
>45\end{array}$ & $\begin{array}{c}- \\
- \\
0.0 \\
20.0\end{array}$ & $\begin{array}{c}10.0 \\
25.0 \\
30.0 \\
-\end{array}$ & $\begin{array}{l}- \\
- \\
- \\
5.0\end{array}$ & $\begin{array}{l}- \\
- \\
-\end{array}$ & $\begin{array}{c}\text { Result } \\
\text { from } \\
\text { Pliocene } \\
\text { Series }\end{array}$ \\
\hline 5 & 93.8 & $\begin{array}{l}<15 \\
<30 \\
<45 \\
>45\end{array}$ & $\begin{array}{l}10.0 \\
25.0 \\
30.0 \\
35.0\end{array}$ & $\begin{array}{l}- \\
- \\
-\end{array}$ & $\begin{array}{l}- \\
- \\
-\end{array}$ & $\begin{array}{l}- \\
- \\
-\end{array}$ & $\begin{array}{c}\text { Result } \\
\text { from } \\
\text { Pliocene } \\
\text { Series }\end{array}$ \\
\hline
\end{tabular}

踐く，表面水と 底面水とでは獎 濁物質に著しい 差がなんもの女 認め，流水它攪 挥世しめ乍いた めこの容器を使 用しを.とのよ らにして探水し

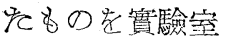
に持ち歸り，次 の方法で䀣濁土 量它測定した。 師ち，震度の異 なる二つの懸濁 液につ々て，粒 徑 $0.01 \mathrm{~mm}$ 以下 分分離し，それ 它比色し，它の 比色此完求め, 次㣙同種の懸 濁液 $1 \mathrm{~L}$ の殘渣 重量学求め如。 この場合の比色 比は $1: 1.12$ で 殘渣重量は夫及 $116 \mathrm{mg} / \mathrm{L}$ 及び $138 \mathrm{mg} / \mathrm{L}$ (1: 1.14) であつて，殆ど一致す る. 份念の䉆粒徑 $0.01 \mathrm{~mm}$ 以下の懸濁液の漂度をいろいろに變えて比色し そ結果は，Fig.2の如くであつて，比色法によつて眯濁土量它測定し\%。 本地域の土壤よりの流去水は色調同一であつて，比色可能である。佮探水

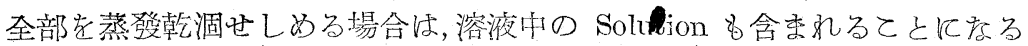
が，乙の場合，雨水の地表流去水であつて，地下水或汗河川水に比べSolutionが極めて少度々(2)ので，その全残渣学懸濁土量としを。

（2）菅原健：降水の化學. 科學 第 18 卷第 11 號 pp. 485 4.92, 


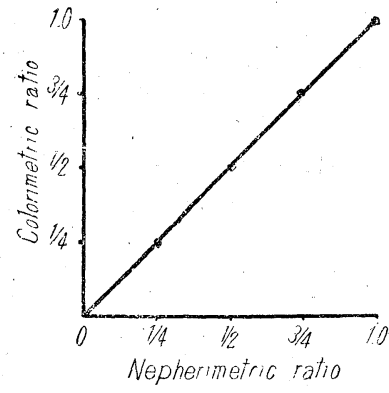

Fig. 2 Relation between Nepherimetric Ratio and Colorimetric Ratio.

レ. St. 1 は林地です 名か，新符三采の砂曆 に横穴が掘られ，その 餘土が租賞榉面積沉亘 つて裸出し，裉さされ ているをめ, St. 5 と

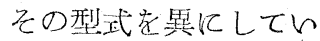
名.

次漱地と林地とに 㗼分し，それらの土壤 流亡度学比較すれ代 Fig. 4. の如くである。 St. 1 ほ前述の如く攪 镝されている先め，一

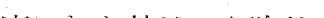

4.土壤流亡度 以上のようにして測定さ。 れを流出土境定各流域につんて比較する光め, 土攘の比流亡量（流亡量／流域面積）乙比流 出水量（Specific rum-off）（流出量/流出面

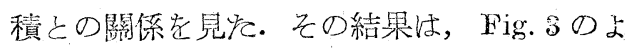
らである。

師方 St. 4. 2. 3 の耕地よ，此流出量の㙕

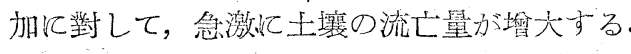
特にローム土壤でない8 系の細粒褐色砂層㲹由來与る）加鼠。土壤流 亡度が大である.St.5 (林地) 壮，比流出量 汃堌加しても，土壤の流亡量は斿ど增加しな

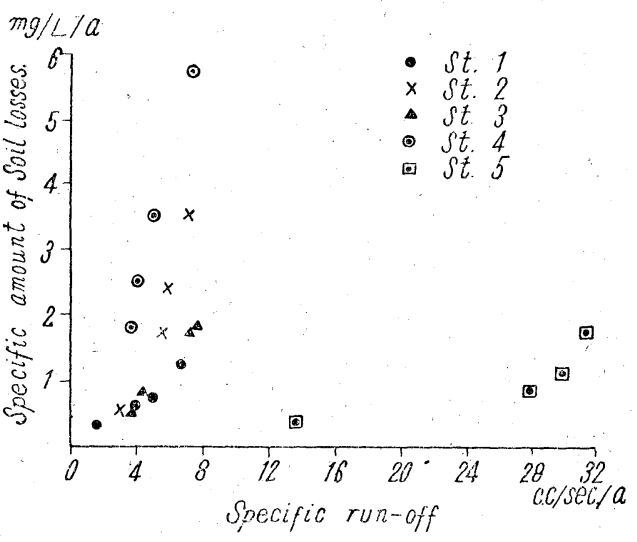

Fig.3 Relation between Specific Amount of Soil Losses and Specific Run-off.

今兩者の鼠係学二次曲綵で表現すると，林地は $y=0.0014 x^{2}$ ，耕地は，

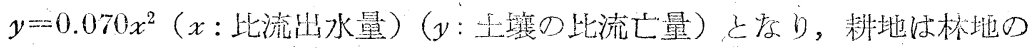
數一倍の信玲量定示している.

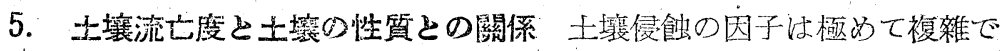
西つて, 多くの因子が結合している. L. D. Baver(3) は侵领因子学次式に

(3) I. D. Baver; Soil Physics. 1940. P. 323 


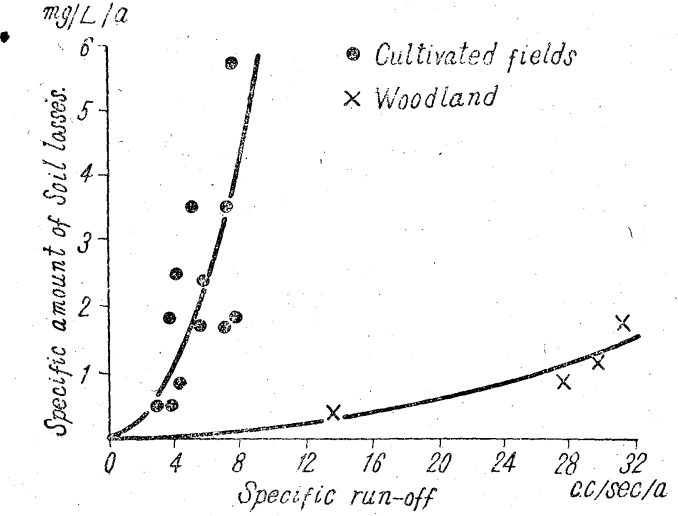

Fig 4 Comparison of Amount of Soil Losses in Cuitivated Fields with that of Woodlands.
よつて表現している。 即方 $\mathrm{E}=\mathrm{f}$ (C. T. V. S. H), 乙\で $\mathrm{E}= \pm$ 墥偦玲 Soil erosion, $\mathrm{C}$ 二氣侯 Climate. $\mathrm{T}=$ 地形 Topography $\mathrm{V}=$ 植被 Vegetation $\mathrm{S}=$ 土壤の性質 Soil charactoristics. $\mathrm{H}=$ 人文 的要素Human factor. 等者は本地域於て 作用するこれ等の因子 について逐次解明 L, 特江壤の物理化學性 と土壤流亡度との關係

を述べる。本稿飞於ては，土壤の物理的性質の一部につんて，そ抗との閣 係を述ベるにとら゙める。

土地の傾斜は，土壤侵蝕の重要索因子であつて，H，H. Bennett(4)が Missouri loam soil に關して, 傾斜 $1 / 27$ 以上では，傾科 $1 \%$ 增す每に侵蝕 は $25 \%$ 壖すとと定報じている。本地域て於ては，自然彇態の谷の\%め複

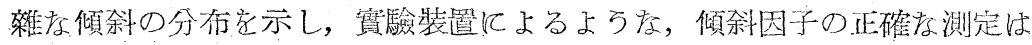
不可能である.Tab.1 飞示し学如く，St.1.4.5 は傾斜分布が類似し， 急斜地多く, St. 2 は緩科地多く, St. 3 は两者の中間の傾斜分布を示して

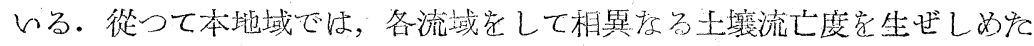

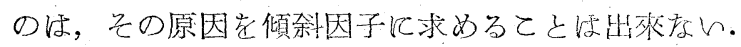

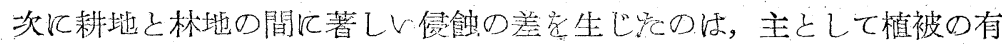
無によつて說明するととが出來る。しかし，赫地相互間の侵玲の差は，單

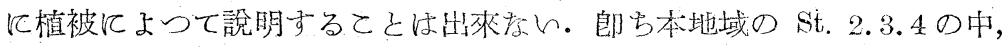
特に St. 4 が最大の流亡度定示したのは，主として土壤の物理化學性によ

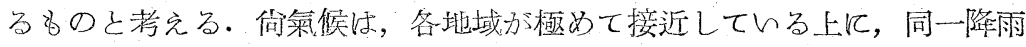

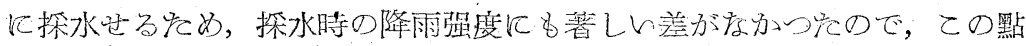

(4) H. H. Bennett; Some Aspect of Soil Erosion as a National Problem, Rep. 9th Mecting Amer. Soil Survey Assoc. 1929. pp. 55-74, 
Tab. 2. Soil Porosity in Natural States.

\begin{tabular}{|c|c|c|c|c|c|}
\hline st. & $\begin{array}{l}\text { Depth } \\
\text { (cm) }\end{array}$ & $\mathrm{G}$ & $\mathrm{G}_{\mathrm{s}}$ & $\omega$ & $1-\frac{G}{G_{S}}(1-\omega) . \%$ \\
\hline \multirow{4}{*}{1} & Surface & 0.61 & 1.92 & 0.51 & 86.32 \\
\hline & 30 & 0.60 & 2.50 & 0.42 & 86.08 \\
\hline & 60 & 0.59 & 2.22 & 0.41 & 84.07 \\
\hline & Mean & & & & 85.49 \\
\hline \multirow{4}{*}{2} & Surface & 0.77 & 2.73 & 0.20 & 77.60 \\
\hline & 30 & 0.70 & 2.31 & 0.35 & 80.50 \\
\hline & 60. & 0.66 & 2.31 & 0.43 & 84.04 \\
\hline & Mean & & . & & 80.71 \\
\hline \multirow{4}{*}{3} & Surface & 0.64 & 2.14 & 0.25 & 78.25 \\
\hline & 30 & 0.55 & 2.03 & 0.25 & 83.50 \\
\hline & 60 & 0.53 & 2.31 & 0.30 & 83.90 \\
\hline & Mean & & & & 81.88 \\
\hline \multirow{4}{*}{4} & Surface & 0.99 & 2.50 & 0.11 & 65.29 \\
\hline & 30 & 0.92 & 2.50 & 0.27 & 72.99 \\
\hline & 60 & 0.94 & 2.50 & 0.27 & 72.26 \\
\hline & Mean & & & $\therefore$ & 70.18 \\
\hline \multirow{4}{*}{5} & Surface & 0.73 & 2.14 & 0.41 & 79.94 \\
\hline & 30 & 0.87 & 2.50 & 0.29 & 75.15 \\
\hline & 60 & 0.83 & 2.50 & 0.30 & 76.90 \\
\hline & Mean & & & & 77.33 \\
\hline $\begin{array}{l}\mathrm{G} \\
\mathrm{G}_{\mathrm{s}}\end{array}$ & \multicolumn{5}{|c|}{$\begin{array}{l}\text { : Apparent specific gravity. } \\
\text { : True specific gravity. }\end{array}$} \\
\hline$\omega$ & : Moist & re con & tent. & & \\
\hline
\end{tabular}

で流亡度に差が生じ 庆とは考えられない。 圣，土地利用の形態 は，何れる小麥と甘 諸の輪作地で，Contour cultivation 定行 つて居り，農蒙から の距㒕名近く，管理 の程度も類似してい るのだ，この點で土 壤の流亡度に差が生 じをのと教えら れをん。以上の理由 により，筆者は，各 流域によつて土壤流 亡度に差美生ザしめ 㫕のは，土壤の性質 である゙と考える。

\section{6. 物理的性繁己} の關绿，a）自然狀 態江於ける孔祘量已。 の關係，筆者は含水

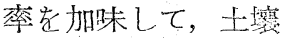
の自然獎態於け名 孔隙量它測定した。 その結果は Tab.2

の如くである・てれによると，殆ど大部分の地域の土壤が Porosity が 70 \%以上で，過大のように見えるが，金子氏(5)の研究によつても，口一ム の自然狀態の孔隙量は 70\%以上飞達するとと定述べている. St. 1.5 の林

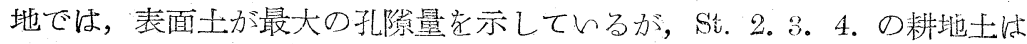

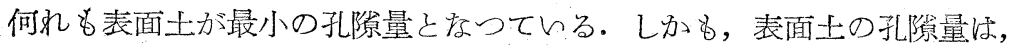

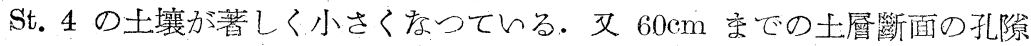
（5）金子是，田地野直哉；口-ム臺地の水. 開拓所究 第 2 卷第 1 號 P.74. 
St. 1

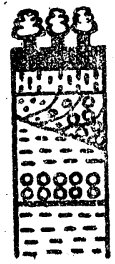

A $20-75 \mathrm{~cm}$ \Loam

B $50-150 \mathrm{~cm} /$ (Mature profile)

false bed.

gravel

clay

brown \& grey sand.

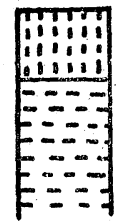

brown sand

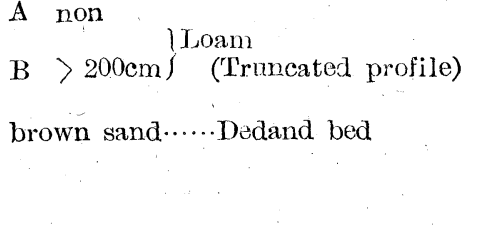

pumice

St. 3

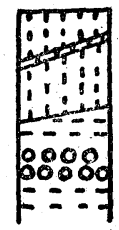

B $\quad 200-500 \mathrm{~cm}$ (Truncated profile)

brown sand Dedand bed

St. 4

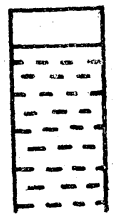

A non

C) $70-80 \mathrm{~cm}$ imperfect differenciation (Truncated profile)

brown fine sand ...... Inagi bed

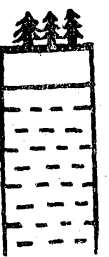

A very thin

B) 70-80 cm imperfect differenciation (Immature profile) taffacious clayey sand...... Kakio bed

Fig. 6 Soil Profile

\section{A non}

量もSt. 4 が何れ上

りも小である.との ことは St. 4 の土層 斷面は，他の地域よ

り是比較的 Compactであるととを示す ものである.とのて とによつて St. 4 は 他の地域より是僅 の雨水で名流去水が 生じ易く，信蝕量が 最大であると教えら れる.郎ちSt. 40 土 壤は表面土の infiltration eapacity \& , 斷面の Permeability 西穴，流去水が生 じ易く土粒が運搬さ れ易々. St. 50 土 壤は，挝面の孔隙量 は小であるが，表面 土の孔陌量が大なを 放 infiltration capacity が比較的大で， しか名樹集，落葉に よつて土壤面か保護 されているので, 比 流出量は大でも，土 壤の流亡は少ない。

一般沉口ーム土壤 は，新第三紀庴より

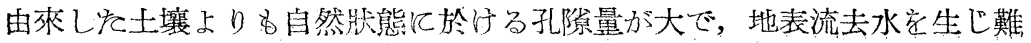
く, 流水による侵蝕它比較的受汀唯々。 
b) 分散比 (Dispersion ratio) との䇫係. 筆者は Middleton ${ }^{(6)}$ の方法

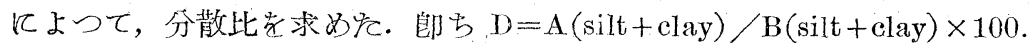

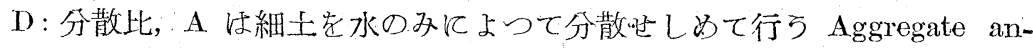

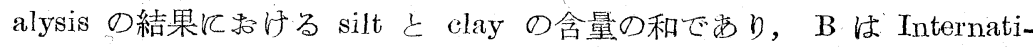
onal A method(7) によつて完全分散せしめて行う所謂 Ultimate analysis の結果によ当 silt と clayの和で手つて，乙れら兩者の比定求め百分率で 表わしたるので西る。

本地域の表面土壤の分散比は Tab. 3 の如くで西る。乙れによると分 散比は林地の St. 1. St. 5 の表土は何れる小であつて， St. 4 のそれが最

Tab. 3 Dispersion Ratio.

\begin{tabular}{c|ccccc}
\hline St. & Depth & Layer & $\mathrm{a}(\%)$ & $\mathrm{b}(\%)$ & $\mathrm{a} / \mathrm{b} \times 100(\%)$ \\
\hline 1 & Surface & A & 16.64 & 75.86 & 21.94 \\
2 & $"$ " & B & 25.80 & 54.50 & 47.34 \\
3 & $"$ & B & 22.26 & 64.86 & 34.32 \\
4 & " & B & 32.43 & 63.22 & 51.30 \\
5 & " & A & 15.30 & 76.32 & 20.05
\end{tabular}

a : Percent of $<0.05 \mathrm{~mm}$ in diameter by aggregate analysis.

$\mathrm{b}$ : Percent of $<0.05 \mathrm{~mm}$ in diameter by ultimate analysis.
大で, St. 2. 3 は前兩 者の中間の值家して いる. 躬ち St. 4 の土 壤は，粒徑 $0.05 \mathrm{~mm}$ 上は，完全分散世しめ 知 Original particles の總計 $63.22 \%$ である が，その中殆ど，50\% 以上が水のみによつて 分散するてとになる。 St. 1.5の㤗土は僅加

$20 \%$ 內外の分散比を持つているに過ざない.かくて St. 4 の土境は，分散

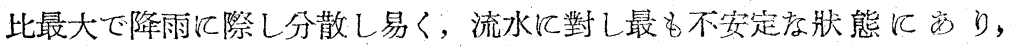

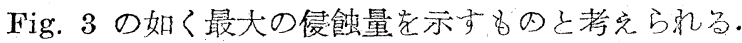

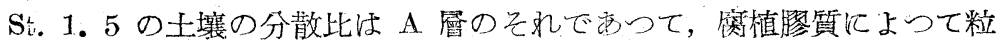

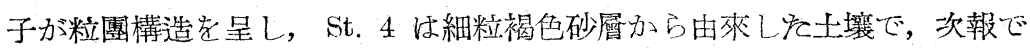

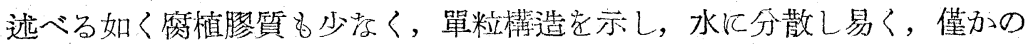
流水に對して为抵抗が小さく，受蝕性である。

この分散比は，土壤の侵赨怡，受蝕性索決定する一うの重要な指標であ

(6) H. E. Middleton; Properties of Soil which Influence Soil Erosion. U. S. Dept. Agric. Techn. Bul. No. 316. 1932. and No. 430. 194.

(7) G. W. Robinson; Soils, their Origin, constitution and Classification. 1936. p. 13.

(8) H. E. Middleton; (6) ibid. 
るとされ(8)，土壤面が打吒を受け㲘濁を生じ，表面流去水が生じて，水の 流動のもと飞於て土壤粒團の安定性字示す民度で西る(9)。

C) 沙泥分散比との關係. 次飞粒洏 $0.05 \sim 0.005 \mathrm{~mm}$ の沙泥部分のみに つ的ての分散比を前項の方法によつて求めると Tab. 4 の如くで㐫る。

Tab. 4 Silt Dispersion Ratio.

\begin{tabular}{c|ccc}
\hline St. & $\mathrm{a}(\%)$ & $\mathrm{b}(\%)$ & $\mathrm{a} / \mathrm{b} \times 100(\%)$ \\
\hline 1 & 11.64 & 26.94 & 43.21 \\
2 & 20.94 & 24.64 & 85.06 \\
3 & 20.76 & 30.34 & 68.42 \\
4 & 23.03 & 28.14 & 81.84 \\
5 & 12.80 & 28.58 & 44.79
\end{tabular}

a: Percent of $0.05 \sim 0.005 \mathrm{~mm}$ in diameter by aggregate analysis.

b: percent of $0.05 \sim 0.005 \mathrm{~mm}$ in diameter by ultimate analysis.

箨者はこの沈泥部分の分散比夌沈泥 分散比と稱する.Tab. 4 飞よれね゙St. 2.4の土壤が沈泥分散比が大で，何れ も $80 \%$ 以上で, St. 1.50 土壤 (A層) は $40 \%$ 內外飞過ざない.St. 3 の土壤 は前兩者の中間の值を示している，極 めて小さい粒子郎ち膠質物の含量が大 き壤懽集力が大であつて，粒子 が粒團化し，流水沉對して抵抗が大で 運船に抗する力が大で㐫る. 一方粒子 汃大に孝ると，重力に上り流水の運搬 作用に抗するようになる。 以上の理由

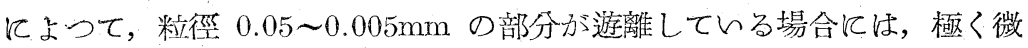
弱な水流飞よつて運搬される。乙の沈泥分散比は，水のみによつて遊離す る量の割合を示するのであつて，沈泥分散比の大な土壤は，より受蝕性で あると言々得る。本地域に於ては，新第三系の細粒褐色砂㬝より由來しを St. 4 の土壤及び，關東ローム㕌のB層は沈泥分散比が大で受蝕性である. このととが一つの原因となつて, Fig. 3 に示しをような土瓖流亡度を生じ をものと考光る。

6. 結語 以上筆者は, 土壤流亡度が土壤の物理的性質の相違によつて, 差学生和るてとを遮べ它。

土壤侵蝕は主として Sheet erosion によつて行われるので，その土壤が 表面流去水が生じ難く，又流去水が生じ它後も，流水に對して抵抗が大度 土壤は耐蝕性である。本地域に於ては，一般にローム土壤は，自然狀態に 於汀る孔隍量大で流去水生じ難く, 分散比及び沈泥分散比も一般に小で, 流水飞對して安定であつて，新第三紀懕より由來しを土壤よりる，耐蝕性 である・終りに本研究に當つては, 東京文理大三野博士の絕大な御指導を

(9) J. F. Iutz; The Relation of Soil Erosion to Certain Inherent. Soil Science. Vol. 40. 1935. pp. 439-457. 
得在てと老感謝するもので西る。（昭和 25 年 10 月 24 日受理）

Relation between the Amount of Soil Losses and

Soil Characteristics.

-The Study on the Soil Erosion. No. 1-

\section{Masami Ichikawa}

The writer's conclusions from his studips on this relation taking Tama Upland as his field, are as follow;-

(1) However complex are the factors to do with soil erosion, soil factor is greater than other factors, in this region.

(2) The soils from pliocene series (St. 4) have suffered more lossses than the Kanto loam soils.

(3) The soil erosion is much severer in cultivated fields (St. 2. 3.4) than in woodlands.

(4) If the soils are porous, rain easily pərmeates into them, making them (St. 1. 2. 3) unstable in such a degree as to cause run-off and erosion.

(5) The dispersion ratio is one of the good indicators which determine the resistability to running water. The dispersion ratio of the cultivated soils -especially St. 4-is larger than that of others.

(6) The silt dispersion ratio of soils is one of the indicators which determine the resistability against erosion. The larger this ratio, the more are soil particles which are unstable to running water. These soils (St. 4. 2) are more liable to transportation and hence to erosion.

(7) Generally spaaking, the loam soils are more resistant to erosion than soils from pliocene series. 